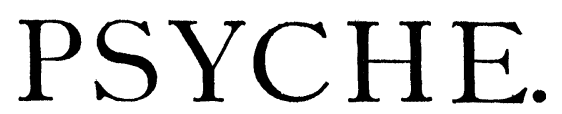

ORGAN OF THE CAMBRIDGE ENTOMOLOGICAL CLUB

EDITED BY GEORGE DIMMOCK AND B. PICKMAN MANN.

Vol. II.] Cambridge, Mass., May-June, 1879. [No. 61-62.

The Anatomy of Amblychila cylindriformis Say.

(With lithographic plate 1.)

LITERATURE.

Imago. Schaupp: On the Cicindelidae of the United States (Bull. Brooklyn Entom. Soc., June 1878, v. 1, no. 2, p. 5).

Larva. Horn: Descriptions of the larvae of the North American genera of Cicindelidae, ... (Trans. Amer. Entom. Soc., 1878, v. 7, p. 28-40, pl. 2.)

See also Brous: Habits of Amblychila cylindriformis (Trans. Kansas Acad. Sci., 1877, v. 5, p. 11-12), and Snow: Amblychila cylindriformis Say (Trans. Kans. Acad. Sci., 1878, v. 6, p. 29-32).

I began the investigations recorded in the present paper in the winter of 1877-8, on the receipt of fifty specimens of $A$. cylindriformis from Mr. George Porter Cooper, of Topeka, Kansas, but dropped the subject in the spring, and only took it up again in January 1879 , on the receipt of fresh material from Prof. F. H. Snow, of the State University, Lawrence, Kansas. I had occasion also to dissect numerous specimens of Omus audouinii, received from northern California and from Prof. O. B. Johnson, Salem University, Oregon.

In comparing the two genera, I find that they differ in several points. Omus has the facets of the cornea of the eye convex, ${ }^{1}$ while in Amblychila the eye is entirely smooth. The accessory

1 Omus and many other Cicindelidae have not only very convex facets on the cornea but also comparatively large eyes, both these characters giving more distant sight than Amblychila has. The cones are biconvex in Omus, while in Amblychila they are only convex interiorly. The more anterior position of the eye in many Cicindelidae gives better sight than a lateral position would give; in the latter case the antennae are of far more use, as organs of touch, than in the former. 
gland of the male sexual organ of Amblychila (Fig. $9 b)^{1}$ is more dilated than in Omus and the bending of the testis is in the reverse direction; there is also in Omus a double pair of long accessory tubes discharging their contents into the vas deferens, each pair of these tubes uniting near their insertion. The tip of the penis is acute in Amblychila (Fig. 13 A) but is rounded in Omus (Fig. $13 \mathrm{~B}$ ). The last abdominal segment is emarginate in all the genera of our fauna except Amblychila. I do not know whether this emargination corresponds with the form or position of the tip of the penis, or not, but it is certain that most, if not all, the species of the different genera fly around in copula, and the emargination may help to make this possible.

In looking over the family of Cicindelidae in a speculatory way, I drew the inference that the line of descent diverged (probably in the mesozoic age) into branches, the lowest ${ }^{2}$ and certainly the oldest of which is still represented in the genus Amblychila. In Omus, Tetracha, Cicindela pilatei, $C$. maga, C. cursitans and C. celeripes we have an aberrant lesser branch, the latter genera being closely linked with the rest of the Cicindelidae.

Contemplating the law of adaptation and heredity, I arrived at the conclusion that the prototype of Amblychila formerly lived on the shores of the great intercontinental gulf in cretaceous times, before the arrival of Cicindela hirticollis and $C$. lepida ${ }^{3}$ and was in those ages provided with a more specialized structure, which by degrees became retrograded and inherited, when its survivors adapted themselves to the clay-banks of the undulating prairies of Colorado and Kansas. It probably formerly led a life, like its congeners in Mexico and South America, on leaves of trees, along the shores of the great gulf; the conseqnent breaking up of the latter into innumer-

1 The figures referred to are on Plate 1.

2 Deficient in organ of sight. less specialized in organs of reproduction and in larva, reduced in abdominal segments and wanting wings.

3 LeConte: Address of Retiring President (Proc. Amer. Ass. Adv. Sci., 1875 [v. 24], p. 1-18), p. 4. Horn: Notes on some coleopterous remains from the bone cave at Port Kennedy, Penna. (Trans. Amer. Entom. Soc., 1876, v. 5, p. 241-245) (Misc. papers on Amer. coleoptera, p. 241-245), p. 241. 
able salt and brackish lakes being the primary cause of its retrogradation. ${ }^{1}$

Owing to the light membranous body of insects, they were less likely to be destroyed ${ }^{2}$ in pre-historic evolutions than were vertebrates and many invertebrates; consequently future researches in the rich deposits of the Rocky Mountain tertiaries may yet reveal the fossil ancestor of Amblychila.

As a secondary adaptation, I mention the pubescence of the middle tibia in the male of Megacephalini and Cicindela (excepting in $C$. pilatei and C. maga, where it is glabrous). It is intended for a firmer hold of the female during copulation; in Amblychila the dilation of the anterior tarsi in the male was dropped as useless, probably owing to the smooth cylindrical thorax of the female, and was replaced by an acute hind trochanter ${ }^{3}$ for firmer insertion into the funnel-shaped pores between the ridges of the elytra of the female. This structure was useless to the female and therefore the trochanter remained blunt. We find similar inherited adaptations in the serrulate and curved middle tibia of Calosoma sayi $;^{4}$ the dilation of the anterior tarsi was in this instance preserved. Although C. sayi occurs frequently in Kansas and thereabouts, its frequency is probably checked by some enemy; its large size, and perhaps other causes, lessen its number. The interrupted elevations between the longitudinal ridges of its elytra are also, perhaps, fit for the acute trochanter of the male.

Whenever we find characters dropped because they are of no apparent use, we find them existing elsewhere, where they are probably also useless. They are merely - as are, for instance, the arthropodous trochanters - rudimentary organs which become important indications in comparative anatomy for tracing their ancestral connections, at the same time teach-

1 LeConte: Classification of the coleoptera of North America, p. 1.

2 LeConte: Address (l. c.), p. 8. "Cataclysms and submergences, which would annihilate the higher animals, would only float the temporarily asphyxiated insect, or the tree trunks containing the larvae and pupae to other neighboring lands."

3 Horn: Sexual characters of North American Cicindelidae ... (Trans. Amer. Entom. Soc., 1875, v. 5, p. 232-240, pl. 1 in part) (Misc. papers on Amer. coleoptera, p. 232-240, pl. 1 in part), pl. 1, fig. 18.

${ }^{4}$ Horn: ibid., pl. 1, fig. 26. 
ing, also, how an organ is apparently preserved without purpose for an indefinite time. In order to understand the teleology of certain inherited organizations it is necessary to be perfectly acquainted with the external conditions and the biology of the respective species. Adapted forms and accommodations are explicable only upon such conditions. Since the determining impulses for transitions and changes in organisms lie outside of the latter, or are to be sought there for the greater part, they thus often escape our observation.

Instances could also be mentioned of sexual peculiarities which seem to be in opposition to easy copulation, yet the species are abundant. Such apparently conflicting facts could undoubtedly be explained if we had full knowledge of the peculiar biology of those species. Amateur entomologists ought, therefore, by accurate biological observations, to concentrate their studies especially upon this generally neglected theme.

\section{ANATOMY OF THE IMAGO.}

Integument. The dark brown elytra exhibit, on the upper side, elevated longitudinal beads and funnel-shaped punctures. In a deeper layer, next to the hypodermis, are several longitudinally meandering cylindrical canals, running between the pores and the beads. The larger, serially arranged pores just reach the chitinogenous matrix (hypodermis), forming a minute protuberance, while the smaller, more or less irregularly placed pores, pierce the matrix. The circular fibrous area of each of the larger pores forming a third group has an interruption, which is always on the side towards the base of the elytra, and appears to be a concave groove, the exact nature of which I did not succeed in disclosing. (Fig. 7.)

On macerating a piece of the head alternately in caustic potash and acetic acid, three different sizes of pigment-granules can be discerned in the cuticula: first, a fine granulation, second, an irregularly arranged coarser granulation, and third, a nearly round, homogeneous assemblage of larger spots.

A broad zone of spinous excrescences, arranged like tiles, extends along the pleurae of the abdominal integument between and around the stigmata. 
Inner skeleton. For the suspension of the pharynx two chitinous furcate processes are fastened to the roof of the anterior portion of the head. Each process has a hook above the pharynx and a membrane at its lower portion, which connects with the other process. (Fig. 12.) Another chitinous process extends longitudinally along the roof of the thorax, and serves for the insertion of muscles. Similar organs have been observed in many other insects, always serving either for the insertion of muscles or for the support of delicate organs.

Alimentary canal. (Fig. 4.) The most anterior muscular portion of the canal, the pharynx, first bends upward, passes through a chitinous diaphragm formed by the above-mentioned processes, and then reaches nearly down to the base of the head. At this point its lower part is contracted by a sort of sphincter pharyngis. The chitinous and membranous continuation, the oesophagus, gradually widens its lumen, and ends with a capacious bladder, the ingluvies, or crop.

The pharynx has two layers, the inner of which consists of quite large glandular cells, occasionally including small tracheal branches. The glandular cells are densely grouped in the transverse and longitudinal folds. The outer layer consists of a sheath of ring-muscles, which are, along the longitudinal glandular cell-folds, covered with a layer of longitudinal muscular fibres. The fibres of the longitudinal muscles are broader than those of the ring-muscles. In order to convey a better idea of the complicated arrangement of the two layers in the pharynx, Fig. 14 is added: $e$ and $d$ belong to the outer, $a, b, c$ and $f$ to the inner layer.

The structure of the membrane of the oesophagus and ingluvies is perfectly homogeneous, the latter taking charge of the maceration of the semi-fluid nourishment and the expulsion of undigested food. The contents of the ingluvies are in all cases a dirty grey emulsion, mixed with a fine, crystalline, sand-like sediment. As Amblychila lives in clay-holes, probably it swallows, along with its food, a quantity of clay, for the purpose of comminuting and crushing its food, with the assistance of the triturating muscles of the proventriculus, as is the case in many other insects. 
The widest lumen of the ingluvies is in the neighborhood of the first abdominal segment. A powerful muscular complex forms the proventriculus, and consists of eight flesh-colored fascicles, a little over $2 \mathrm{~mm}$. long, convex outside and concave inside at the base. The broader bases of the fascicles are closely fitted to the proventriculus, and their pointed ends are turned backward. Two of these eight fascicles are connate, exhibiting a deep longitudinal fold at their connection. Each fascicle terminates in a chitinous tooth, and the entire complex is covered with tooth-shaped excrescences, or aciculi, directed backward and outward. The same apparatus exists in Omus and in many other insects. ${ }^{1}$ In the larva of Corethra, a dipteron, these spines are directed toward the lumen of the pharyngeal bulb, forming a sort of weir-basket, and the mechanism as well as the function of this apparatus must be different from that of the complex in Amblychila.

Just behind the proventricular apparatus three pairs of Malpighian vessels discharge their contents into the very narrow and compactly muscular chylific ventricle. They are of considerable length, winding themselves through the lobes of the corpus adiposum, but are not in any way extraordinary, having the histological structure of Malpighian vessels in other insects.

Four other short, yellow sheaths, or utricular organs, also discharge into the chylific ventricle. Their envelope shows very fine, transverse lines, which do not, under high magnifying power, prove to be ring-muscles. The contents of these sheaths is an aggregation of closely packed, glandular lobules. I assume them to be functionally the so-called pyloric appendages. They neither precede nor follow the Malpighian vessels but are closely intermingled with the latter, and only with difficulty can be traced to their insertion.

The anterior portion of the chylific ventricle, connected with the Malpighian vessels and pyloric appendages, consists of a thickened external layer of fine fibrous network with large meshes, having from three to six yellowish glandular lobes enclosed in each mesh. (Fig. $8 a$ and b.) The anterior part of

1 Burmeister: Handbook of entomology, translated by Shuckard. 1836. 
the chylific ventricle, with its glandular envelope, is probably the true digesting portion, and the posterior part serves for the absorption of chylified fluid:

The course of the chylific ventricle is straight. Its length, in contracted alcoholic specimens, is about $25 \mathrm{~mm}$.; its diameter, $1.5 \mathrm{~mm}$. Owing to its tough muscular substance, it is supposed to be capable of extension and contraction, and to have peristaltic motions, in the living animal.

The chylific ventricle terminates with a sort of sphincter, reaching into the third and last part of the alimentary system, the rectal bladder (Fig. $4 g$ ).

The rectal bladder is of the same form as the ingluvies and, like the latter, is a capacious organ with thin, chitinous walls. Its widest lumen is toward the chylific ventricle, and it gradually narrows to within about $3 \mathrm{~mm}$. from the anal orifice, to which extends a narrow muscular tube. Shortly before reaching this tube the rectal bladder is provided with glandular, longitudinal folds like those mentioned in the pharynx.

Six ellipsoidal bodies, rectal cells (Fig. $4 h$ ), equidistant from each other, form a sort of girdle around the widest part of the bladder. Similar organs have been observed long since in other insects, and much has been written about them, to which I can add but little. Omus has them. Their physiological action has not been sufficiently explained, though, in general, they are regarded as excretory organs.

The rectal cells of Amblychila are $2 \mathrm{~mm}$. long, and about $0.9 \mathrm{~mm}$. wide (Fig. 5), and have a chitinous, lemon-colored wall, consisting of four lavers (Fig. 6). The central part is filled by a simple cell-layer, consisting of an aggregation of large, colorless cells, closely packed and therefore appearing oval-polygonal. The outermost layer of the wall is the narrowest, and is colorless and structureless; the second is onehalf broader, colorless and structureless; the third is as broad as the two outer together, yellow, convex outwardly and structureless; the innermost is as broad as the second outer, yellow, and exhibits under high power, glandular canals running toward the large central cells. The latter are plainly nucleated. 
Circulatory system. There is, as in all insects, a contractile (pulsating) dorsal vessel, with venous ostia and arterial branches; but it was impossible for me, in the numerous specimens received in a dampish condition, to find the dorsal vessel or its ramifications, which would have been easily done in living individuals.

Respiratory system. Amblychila has seven pairs of stigmata (nine in the larva). The tracheae present a diversified system of ramifications, with the occasional occurrence of dispersed tracheal expansions, or bulbs, in the smaller branchlets, as is the case in other insects. Correspondences occur between the tracheal system and many of the other organs (corpus adiposum, integument and muscles), whereby an aeration of the blood is not only possible in all parts of the body but also in the respective tissues themselves.

The respiratory system assists locomotion by considerably lessening the specific gravity of the body.

Muscular system. But little can be said about the muscular system of Amblychila, though a few general remarks may be useful and instructive. As in all arthropcda the muscles are individualized, consisting of a number of single fascicles of fibres. The wings are wanting and the elytra connate, consequently the muscles destined for the wings are rudimentary. A number of leg-muscles are inserted on both sides of interior prothoracic processes. Stout fascicles in the head move the oral organs of this carnivorous insect. Several ligaments and membranes connect the head with the thorax, and the latter with the abdomen. The pharyngeal muscles have been mentioned before.

As is the case in all arthropoda the muscular fibres are transversely striate. Since I received only dead specimens, I could find only striate muscular fibres; striate fibres also occur in living insects, however, as Franz Leydig and August Weismann showed in the larva of Corethra.

Nervous system. (Fig. 1.) I succeeded in tracing the nervous system in several individuals. Having macerated the bodies in water several days, I opened them from above, at the sides, and having carefully removed corpus adiposum, digestive 
tract, genitals and side-muscles, the nervous cords, with their ganglia, can be seen with the naked eye, lying along the median line of the body on the under muscular sheet.

The supraoesophageal ganglion measures from its middle to the cornea of the eye a little less than $2 \mathrm{~mm}$, and is more convex than the infraoesophageal ganglion, with which it is connate at the sides. The widest diameter of the infraoesophageal ganglion is $1 \mathrm{~mm}$., and it is about $0.6 \mathrm{~mm}$. thick. At the side of the supraoesophageal ganglion arises the optic nerve, and near the posterior part of the base of the latter, the antennal nerve. From the ventral surface of the infraoesophageal ganglion arise two pairs of fine nerve-threads, but whether they extend to the mouth-parts, or whether they are sympathetic branches, I cannot say. The infraoesophageal ganglion is connected with the first thoracic ganglion by two commissures, and the other ganglia are connected in the same way. There are five abdominal ganglia, of which the last two are nearer together than the others. The terminal commissures run, in the females, into the base of the ovipositor, but as this would be an anomalous place for a sixth ganglion, I think they subdivide themselves into smaller branches.

The soft tip of the terminal joint of the labial palpus is covered with an area of fine papillae.

Directly above the eyes in all Cicindelidae, and in the larvae of Amblychila, Omus, Tetracha and Cicindela, are three stout bristles. Judging from their position and constancy, pu obably they have a sensorial function, either as organs of touch, or, what is more likely, as auditory organs.

The biological notes of Prof. F. H. Snow and of Mr. H. A. Brous teach that Amblychila has "a very poor eye-sight and an acute sense of touch, chiefly concentrated in the vibratory antennae." Burmeister says, " "Organs of touch they (the antennae) cannot be, for their surface is too hard and horny, and besides, all insects have for this purpose organs furnished with a very delicate touching-substance ..." The numerous bristles on the antennae of Amblychila and of other insccts

1 Burmeister: tr. by Shuckard, p. 485. 
sufficiently warrant their being organs of touch and later investigations agree with this view.

The apparently typical, dorsal plates of the fifth abdominal segment of the larvae of Cicindelidae will have to be considered, I suppose, as organs with sensorial functions, but this supposition is in need of exact observation. They are usually regarded as claspers. ${ }^{1}$

Corpus adiposum. The adipose body does not present anything extraordinary. The larger lobes are above and at the sides of the digestive tract, and are dirty-white, presenting, when magnified, roundish globules enveloped in connective tissue. The globules consist of very tender and undulate lamellae. The larger lobes of the corpus adiposum are also enveloped in a sort of tissue, and here and there receive small tracheal branchlets, an arrangement which serves to keep the adipose body in position.

Numerous roundish, white corpuscles, of a diameter of 0.2 to $0.5 \mathrm{~mm}$., are found dispersed over and between all the internal organs, undoubtedly organic matter secreted from the corpus adiposum through the general transelementation.

Female sexual organs. The cylindroid-oval eggs are apparently free, imbedded in the body cavity. In the condition in which I received the specimens, the finer ovarian membranes were wholly broken up. Specimens caught at a different season would undoubtedly have been more interesting. I found the eggs of equal size, and vainly searched for less developed ones. There are from three to six eggs in each individual. The length of the egg is about $4 \mathrm{~mm}$., its width not quite $2 \mathrm{~mm}$.

The brown coagulated deutoplasm, or yolk, has no yolkmembrane. It lies loose and considerably contracted in the
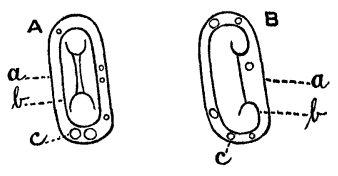

Fig. 10. A, ventral view; $\mathbf{B}$, lateral view; $a$, chorion; $b$, deutoplasm; $c$, oil-globules. hyaline chorion. The two poles of the deutoplasm are, in every instance, contracted to one side, which, for convenience, I will call the ventral side (Fig. 10 , this page). Between the deutoplasm and the chorion are several yellow oilglobules, irregularly dispersed, having 
been squeezed out of the yolk at the time of its contraction by alcohol. The chorion exhibits quite large, irregularly roundish cells (Pl. 1, Fig. 10), and as their cell-walls are elevated, this form of chorion may be called cancellate.

I succeeded in finding the micropyle in nearly all the chorions examined, after treatment with chloroform and alcohol, and preparation in glycerine. I recommend, therefore, eggs of Amblychila to microscopists who desire to examine micropyles. The large size of the chorion, and the ease with which it is removed from the yolk, considerably facilitate the finding of the micropyle (Fig. 11). The margin of the micropyle is circumscribed by a slightly thickened circumvolution or bead, the inner margin of which has six to seven incisures. From this circumvoluted margin radiate stolons, which meander through the granulations and rugosities of that portion of the surface of the chorion. This rugosity is coarser the farther it is from the micropyle, until it finally merges into the polygonal chorioncells. By this zone, or areola of rugose surface, the micropyle is readily recognized, and cannot escape the eye of a close observer. I think the central disk is extremely finely porous, but as I could avail myself of no very high microscopic power, I could not settle this point. Through this perforation the spermatozoa probably gain access to, and fertilize the egg.

Male sexual organs. ${ }^{1}$ The male sexual organs of Amblychila are quite-large in comparison with the size of the insect. (Fig. 9.) The upper, terminal portion, which I consider the testicle, bends itself, with its thinner part to the right, and rests on the middle portion, the latter being bent to the left, over the base of the penis. The upper portion has a stout, longitudinal, muscular wrapper; the thinner middle portion has a thick wall with an apparently glandular epithelial lining. It is more transparent than the other portions. In its lumen, and on dissected parts, under the influence of acetic acid, a sheath or canal is visible,with its upper end bent over (like a parasitic nematode). This canal begins in the lower part of the thin, twisted portion of the middle section and can be traced

\footnotetext{
1 To avoid reiterations concerning the morphology of the organs of copulation, I must again refer to Burmeister's Handbook of entomology.
} 
downward into the terminal combined portion. This canal is the vas deferens, and its muscular, unpaired terminal part is the ductus ejaculatorius.

The middle portion, next below the testicle, on account of its histological structure, I consider a glandular tube, one of the accessory organs.

Carl F. Gissler.

$$
\text { Brooklyn, E. D., N. Y. }
$$

\section{BIBLIOGRAPHICAL RECORD.}

(Continued from page 232.)

The date of publication, here given in brackets [ ], marks the time at which the work was received by the Editor, unless an earlier date of publication is known to him. An asterisk * before a title is the Recorder's certificate of accuracy of quotation. Corrections of errors and notices of omissions are solicited. - B. Pickman Mann.

Nos. 1148 to 1266 are from Can. entom., 1877, v. 9.

* 1148. Bruner, Laurence. Black variety of P. turnus. (Can. entom., 1877, v. 9, p. 20.)

Relative abundance of the black and the yellow varieties of Papilio turnius $\$$ in different parts of Nebraska. [Feb., 1877.]

* 1149. Grote, A: Radcliffe. New Noctuae. (Can. entom., 1877, v. 9, p. 21-22.)

Describes Glaea carnosa, Fishia, F. enthea $=1$ n.g., 2 n. spp. from Maine; notes on 3 spp. [Mar., 1877.]

* 1150. Chambers, Vactor Tousey. Tineina from Texas. (Can. entom., 1877, v. 9, p. 22-26, 71-74.)

Descriptive and synonymical notes upon about 16 spp. [Mar., May, 1877.]

* 1151. Grote, A: Radcliffe. Notes on a collection of Canadian moths made by Wm. S. M. D'Urban, and named by F. Walker. (Can. entom., 1877, v. 9, p. 27-29.)

Synonyms of species described by $\mathrm{F}$. Walker, in the Canadian naturalist and geologist, v. 5, p. 91-96 and v. 6, p. 36-41; also of species labelled in the collection. [Mar., 1877.]

* 1152. Edwards, W: H: Descriptions of a new species of Pamphila from Colorado. (Can. entom., 1877, v. 9, p. 29-30.)

Describes $P$. snowi n. sp. [Mar., 1877.]

* 1153. Saunders, W: The Luna moth - Actias luna, Linn. (Can. entom., 1877, v. 9, p. 31-33, fig. 1.)

Description of imago and larva; figure of imago; food of larva. [Mar., 1877.] 


\title{
PLATE 1.
}

\author{
(Drawn and engraved by C. F. Gissler.)
}

\section{EXPLANATION OF FIGURES.}

Fig. 1. Nervous system of Amblychila. Natural size.

$a$, antennal nerve [natural position is behind the optic nerve]; $b$, eye; $c$, supraoesophageal ganglion; $d$, infraoesophageal ganglion; $e$, first thoracic ganglion; $f$, second thoracic ganglion; $g$ to $k$, first to fourth abdominal ganglia; $l$, terminal cords; $m$, fifth abdominal ganglion; $n$, ventral pair of nerve cords arising from the infraoesophageal ganglion.

Fig. 2. Optic nerve with swelling and ganglionary expansion. Enlarged.

Fig. 3. Vertical section through cornea and crystalline lenses; the latterare convex, interior prolongations of the cornea. Enlarged.

Fig. 4. Alimentary canal. Slightly enlarged.

$a a$, pharynx; $a$, oesophagus ; $b$, ingluvies; $c$, proventricular triturating muscular, apparatus; $d$, Malpighian vessels (shortened); $e$, accessory glands (shortened); $f$, chylific ventricle; $g$, rectal bladder; $h$, rectal cells.

Fig. 5. A rectal cell, moderately magnified.

Fig. 6. Wall of a rectal cell, highly magnified.

Fig. 7. Elytral pores.

$a$, small and plain pore of the elytron: $b$, large ring-pore of the elytron; $c$, large ring-pore interrupted by a concave groove.

Fig: 8. Anterior external coat of chylific ventricle.

$a$, fibrous network moderately magnified; $b$, one of the meshes highly magnified.

Fig. 9. Male sexual organs. Slightly enlarged.

$a$, testicle; $b$, vas deferens (the swollen part = vesica seminalis); $b b$, Ductus ejaculatorius; $c$, process of preputium; $c c$, base of penis; $c p$, preputium; $d$, penis; $e$, distending process; $e e$, corneous ridge of preputium.

Fig. 10. Chorion of egg. Magnified.

Fig. 11. Micropyle of chorion. Highly magnified.

Fig. 12. Chitinous process in head. Enlarged.

$a$, bifurcate insertion; $b$, process ; $c$, membrane.

Fig. 13. Penis. Slightly enlarged.

A, of Amblychila; B, of Omus.

Fig. 14. Portion of pharynx. Moderately enlarged.

$a$, tracheal branch; $b$, longitudinal glandular fold; $c$, polygonal glandular cells; $d$, ring-muscles; $e$, longitudinal muscle-fibres; $f$, transverse glandular fold. 


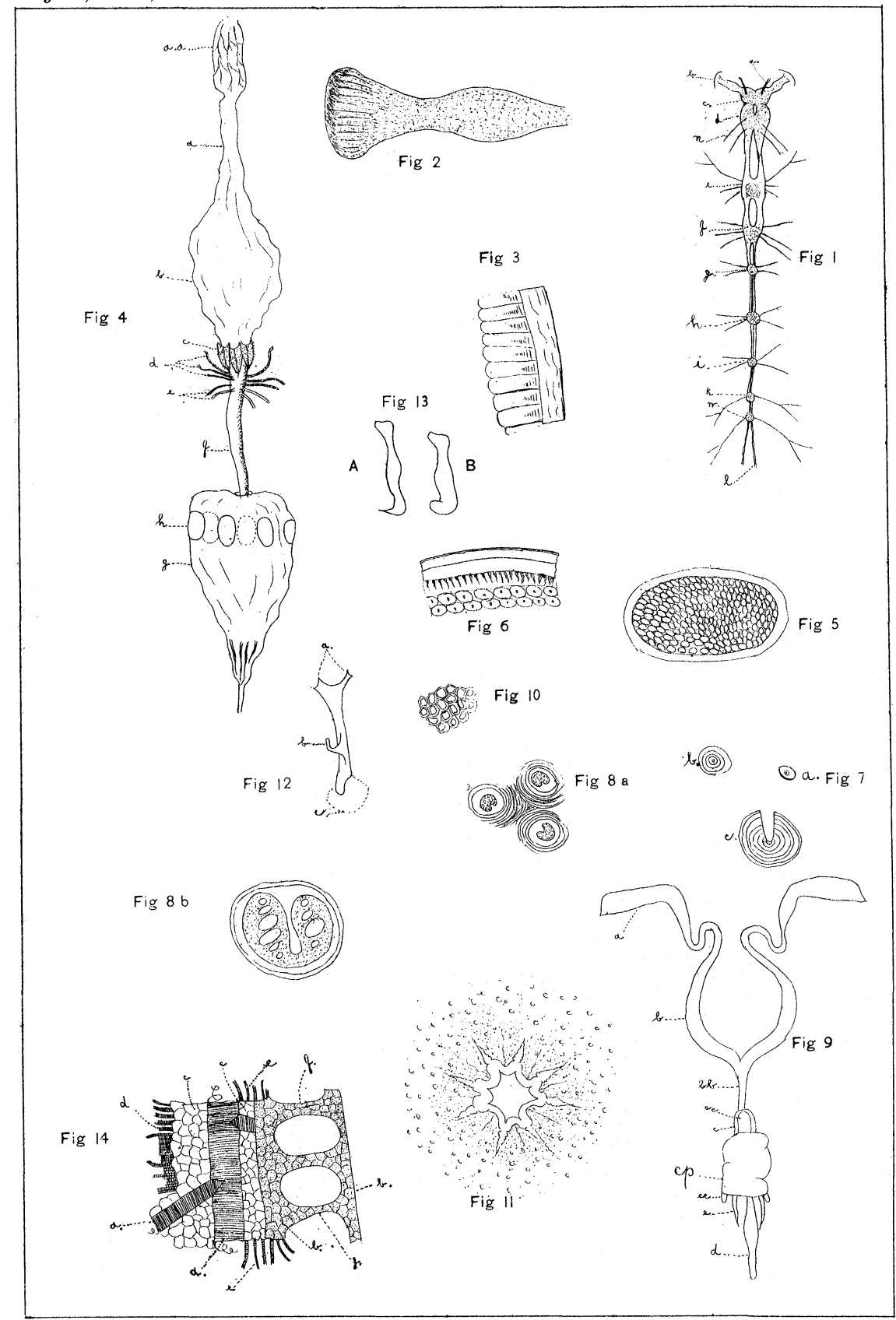

C. F. Gissler, del. et sc. 

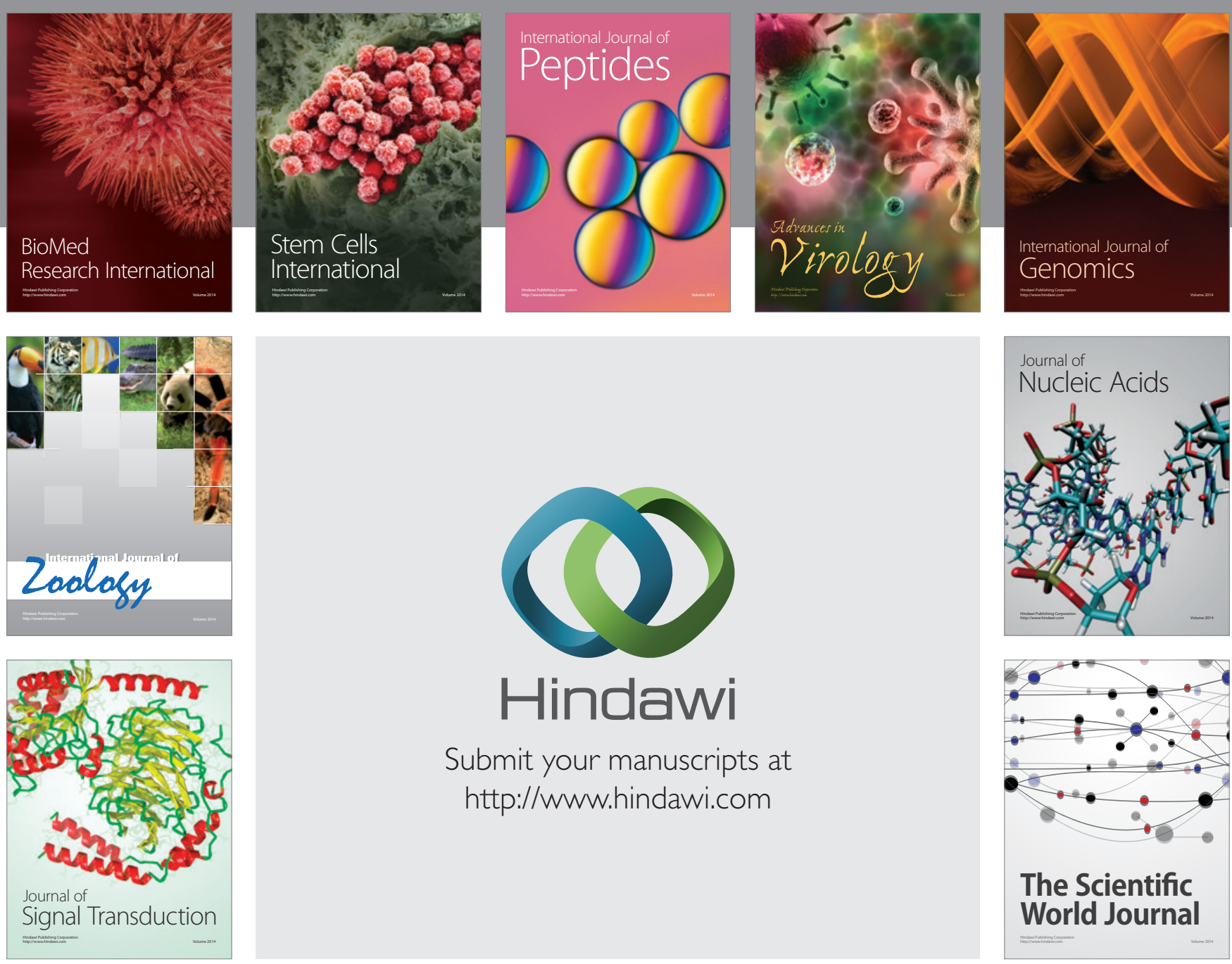

Submit your manuscripts at

http://www.hindawi.com
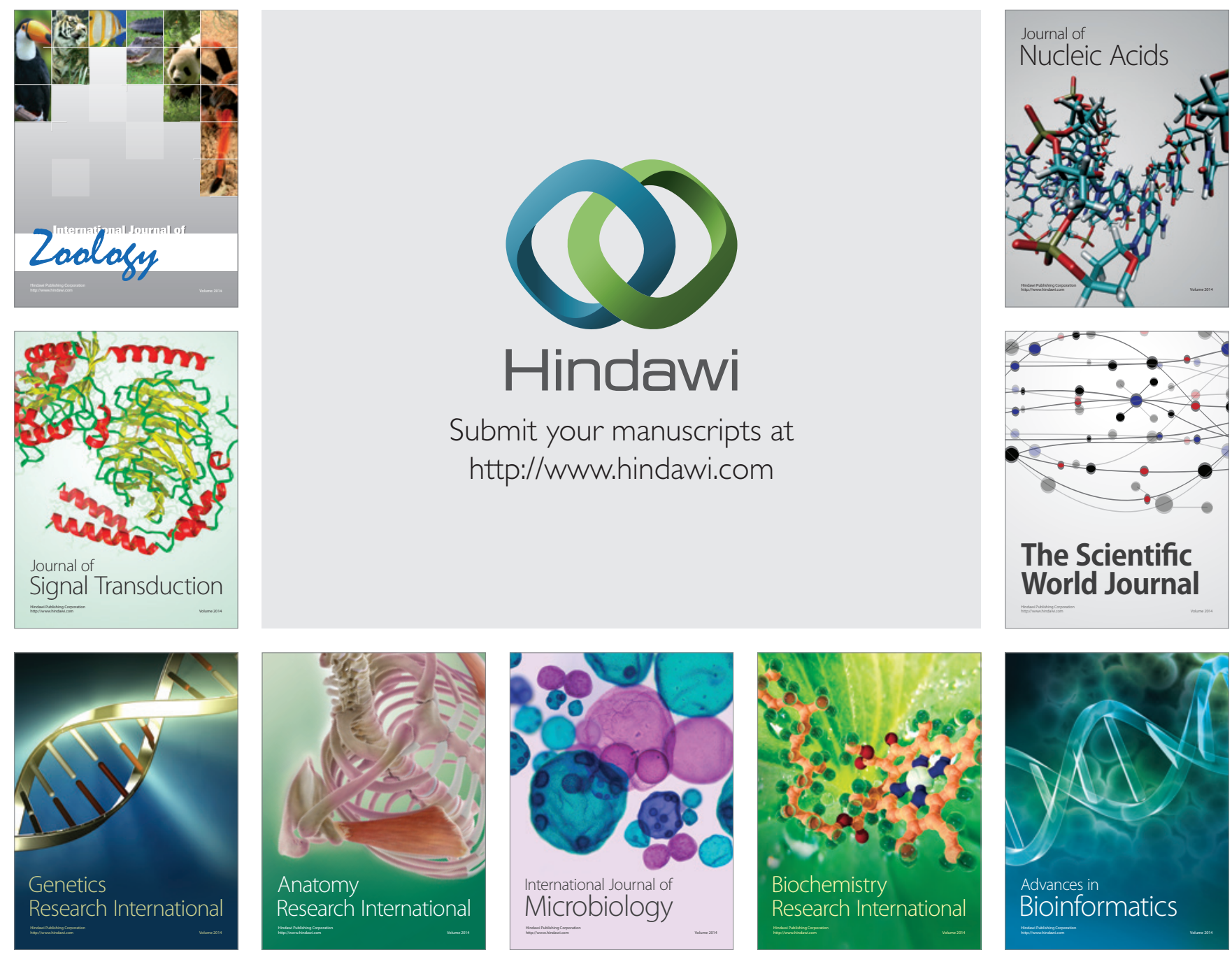

The Scientific World Journal
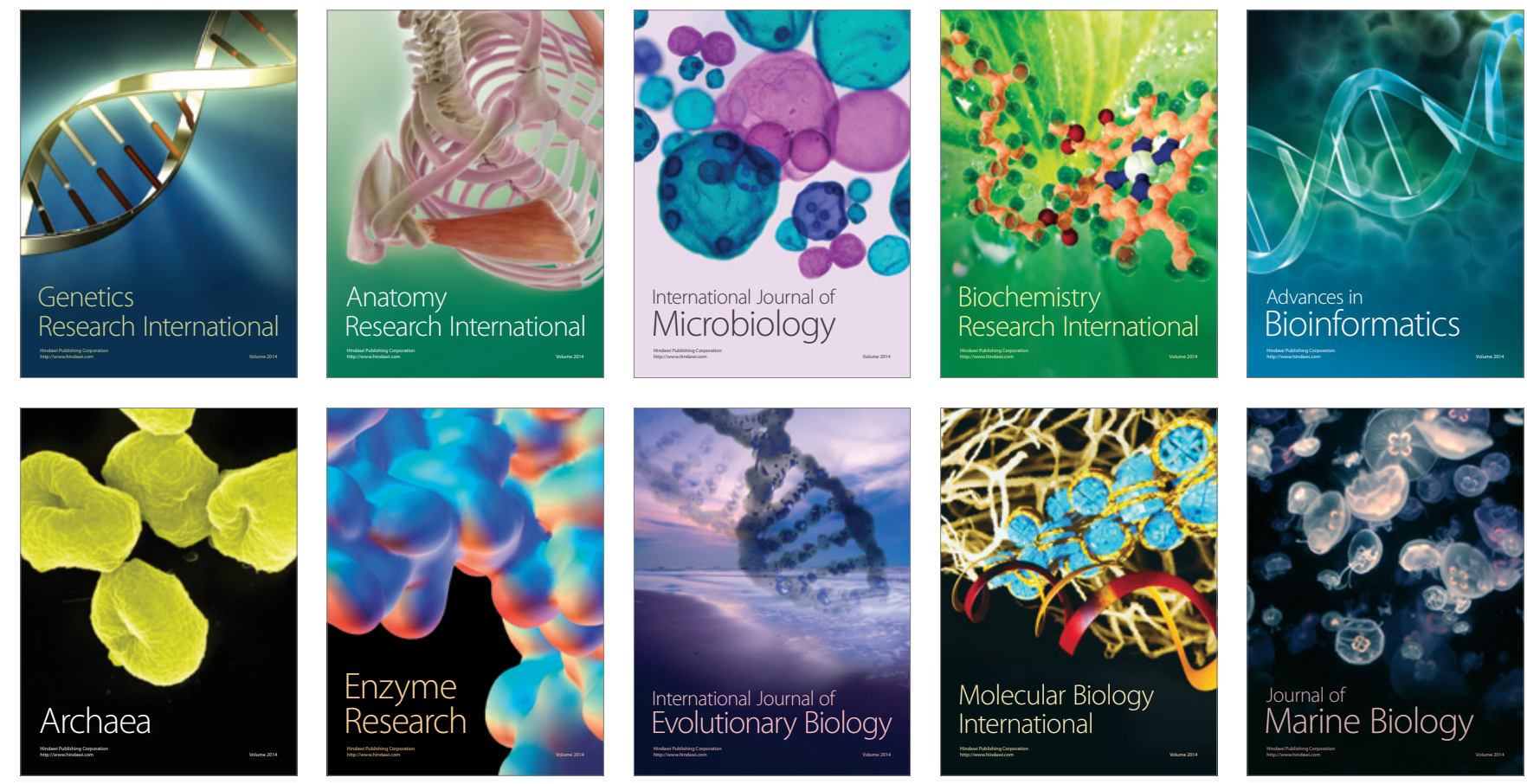